\title{
aniki
}

Revista Portuguesa da Imagem em Movimento

\section{Editorial v6n1}

Os Editores

Este é um número singular na história da Aniki. É o primeiro a ser publicado sem qualquer membro da equipa de editores fundadores. Desde 2014, o corpo de editores foi-se alterando pontualmente, assegurando sempre uma espinha dorsal que remetia à equipa de trabalho que a pensou e a estruturou. Em maio de 2018 deu-se mais uma renovação no corpo editorial da Aniki. No entanto, ao contrário das anteriores, esta significou, de uma assentada, uma alteração completa dos seus editores, com tudo o que isso pode implicar em termos de processos e fluxo de trabalho.

Neste momento, quando apresentamos o primeiro número da nossa responsabilidade, sentimos a necessidade de expressar publicamente o nosso agradecimento às equipas editoriais que nos antecederam, muito particularmente a do biénio 2016-2018, pelo importante trabalho que desenvolveram na afirmação e no reconhecimento internacional da Aniki. A esses editores, muito em particular ao Tiago Baptista, presente na revista desde a sua fundação e coordenador editorial da equipa anterior, devemos uma herança de prestígio, com uma revista de referência nas nossas áreas científicas.

Quando delineamos o nosso projecto editorial, definimos alguns pontos essenciais: a) dar continuidade e consolidar as linhas orientadoras apresentadas pela última equipa editorial, nomeadamente as boas práticas de independência, excelência científica e rigor editorial dos trabalhos publicados; b) continuar a incentivar e a coordenar a organização de dossiers temáticos, visando a revisão e consolidação de áreas de estudo (tradicionais e emergentes) situadas no âmbito científico da revista; c) garantir a colaboração de investigadores com qualidade inequívoca na coordenação dos dossiers temáticos e na revisão cega de pares dos trabalhos propostos para publicação; d) continuar a garantir o acesso livre e a não-cobrança de quaisquer taxas de submissão, revisão, publicação, distribuição ou acesso aos trabalhos publicados pela Aniki. É este o nosso compromisso.

Para desenvolver esta estratégia, contamos com a confiança dos autores que nos submetem os seus textos, fruto do seu trabalho científico de elevada qualidade, com a colaboração dos revisores de 
diversas latitudes geográficas e científicas que asseguram uma avaliação rigorosa e independente e que contribuem, também com sugestões e comentários construtivos que reforçam a qualidade dos textos que publicamos.

Fruto dessa procura, cada número tem procurado responder aos crescentes níveis de exigência que têm pautado o meio académico. Para esta edição, recebemos 33 textos para as secções sujeitas a revisão cega por pares: para o Dossier Temático "O visionamento e a crítica de séries de televisão", coordenado pelo editor convidado Sérgio Dias Branco (Universidade de Coimbra), foram submetidas 18 propostas, cinco das quais percorreram todo o processo com sucesso; para a secção Ensaios foram submetidas 25 propostas, sendo que apenas uma foi publicada neste número, enquanto duas ainda se encontram em processo de revisão. Nas restantes secções, que não estão sujeitas ao processo de revisão cega, o controlo da qualidade dos textos é assegurado pelos respectivos editores residentes. Destacamos a entrevista feita ao cineasta Pedro Costa, conduzida por Ricardo Vieira Lisboa, a propósito da sua intervenção no processo de restauro digital dos filmes Os Verdes Anos (1963) e Mudar de Vida (1966), do cineasta Paulo Rocha.

Finalmente, não podemos esquecer os nossos leitores, que fazem com que todo este trabalho de dezenas de pessoas valha a pena. São cada vez mais, espalhados por diversos países, com particular incidência em Portugal e no Brasil, que reconhecem a utilidade e a qualidade dos nossos textos ao citarem-nos nos seus trabalhos, nas suas publicações, nas suas aulas e nas comunicações que promovem.

A todos, o nosso renovado agradecimento e votos de excelentes leituras!

Paulo Cunha, Sofia Sampaio, Lúcia Ramos Monteiro, Jorge Palinhos e Mickaël Robert-Gonçalves. 